\title{
Between factoids and facts: The application of 'evidence' in NGO strategic communication on war and armed conflict
}

Media, War \& Conflict 2018, Vol. II (I) 85-106

(C) The Author(s) 2017

Reprints and permissions: sagepub.co.uk/journalsPermissions.nav DOI: 10.1 I77/I7506352I7727308 journals.sagepub.com/home/mwc

\section{Romy Fröhlich and Marc Jungblut}

Ludwig-Maximilians-University of Munich, Germany

\begin{abstract}
NGOs are significant actors in conflict-related discourses and play a key role in the shaping of mediated conflict communication. Since previous scholarly work has rarely analyzed the way NGOs characterize the 'reality' of violent conflicts, this contribution to the special issue focuses on the publicity of NGOs in this field. On the basis of a big-data content analysis, the authors in particular investigate the epistemological status of NGOs' strategic communication on war. They focus on 'evidential claims', the actual provision of evidence and the transparency of sources of evidential claims. The results are compared across different types of NGOs for their communication on six international armed conflicts. The findings suggest that the communication of NGOs in this is caught between their role of a strategic communicator and that of an expert. Improvement is especially needed concerning the indication of sources of evidential claims: 47 percent of all texts do not provide any source specification.
\end{abstract}

\section{Keywords}

big-data analysis, computer-assisted content analysis, epistemology, evidence, NGOs, strategic communication, war/armed conflict

\section{Introduction}

In war and armed conflict, few things are as valuable as dependable communication, verified information, and evidence. To understand how public discourse constitutes reality and evidential truth in times of war, it is not sufficient to analyze media news content. Instead, one must also investigate the persuasive communicative activities/strategies of

\footnotetext{
Corresponding author:

Marc Jungblut, Department of Communication Studies and Media Research, Ludwig-Maximilians-University Munich, Oettingenstrasse 67, Munich 80538, Germany.

Email: Marc.Jungblut@ifkw.Imu.de
} 
other key actors involved in the formation of public discourse on war and armed conflict. Among other actors, this includes NGOs (Fröhlich, 2014), which can behave like professional information brokers with their own source networks, intelligence tools, and local experience, utilizing various public and non-public activities such as PR campaigns, media relations, or policy briefs.

NGOs are significant actors in conflict-related discourses and play a key role in the shaping of mediated conflict communication (see Van Leuven et al., 2015). Although they increasingly circumvent the media as gatekeepers and distribute their content directly to their target group(s) via strategic communication ${ }^{1}$ (Seo et al., 2009; Thrall et al., 2014) - Powers (2014: 103) refers to it as 'information production outside the newsroom' - NGOs' media relations remain a very important part of their overall strategic communication. With Zoch and Molleda (2006), we view media relations as a particular strategic function of strategic communication. However, as Supa (2014: 7) rightly states, very little research examines 'media relations on its own as a strategic function of public relations'. As a result, previous scholarly work has only rarely analyzed the way NGOs characterize the 'reality' of crisis within their persuasive strategic communication (Van Leuven and Joye, 2014). This is astonishing for two reasons: firstly, as Gershkoff and Kushner (2005: 526) state, 'it is the interpretation of the events by elites, rather than the events themselves, that help shape public opinion.' Secondly, persuasive strategic communication - the 'conscious and purposeful construction and management of communication' (Maltby, 2015: 167) - also involves defining 'reality' (Weick, 1969), meaning it is highly relevant to investigate this kind of public communication beyond media coverage. Or in the words of Powers (2014: 104): 'bringing empirical research into conversation with the often-underexplored normative underpinnings of NGO publicity remains an important scholarly concern moving forward.'

Therefore, our contribution focuses on normative aspects of strategic communication of NGOs in the field of war and armed conflict. Does their strategic communication conform to normative requirements as defined by theoretical concepts of excellence and best practice in strategic communication? In particular, we consider the provision of evidence in NGOs' strategic communication material as a key component of their discursive truth strategy and a measurable criterion for the success of NGOs' strategic communication in terms of its media resonance. With this approach, our study contributes to the analysis of (news) content production by actors outside the newsroom. For this purpose, we developed a specific content-analytic approach to evaluate the strategic communication of NGOs on war and armed conflict. This evaluative tool may also contribute to the further development of conflict analysis in general, such as when deciding on the reliability and verification of NGO information as facts or factoids. We assess three conflict regions selected for investigation in the INFOCORE project, which also provides the general data basis for the study at hand: the Great Lakes region of Africa, the Western Balkans, and the Middle East. This cross-conflict comparison aims at providing external validity to our results. These show that, depending on particular external factors and variables, almost half of the texts distributed by the NGOs under investigation fail to provide sources of evidence for their claims. We have shown elsewhere (Fröhlich and Jungblut, 2016) that the absence of evidence in NGOs' strategic communication material results in lower media resonance for those NGOs and vice versa, which substantiates our 
normative assumptions on best practice in PR ascribing the provision of evidence an important role for the success of persuasive strategic communication. With this result, our study can also confirm selected key criteria for excellence in strategic communication which have been developed in normative PR theory.

\section{Literature review and theoretical framework}

NGOs have traditionally relied on strategic communication as a cost-effective way to reach different publics and achieve certain goals (see Taylor et al., 2001). It has gone on to become a key strategic tool for NGOs, represents a new means of gaining access to media, public discourse and opinion, and makes NGOs issue managers (Smith and Ferguson, 2001). However, the importance of strategic communication for NGOs contrasts with the small amount of research that has been done on the subject. Therefore, we allow ourselves in the following to (also) rely on research and literature about the strategic communication of activists and interest groups. Referring to Bloodgood (2011), we are convinced that those works can be applied to NGOs.

With Curtin (2016: 20), we concur that the strategic communication of activists (NGOs) is 'a form of public discourse' which aims to 'promote, maintain, and resist dominant political and economic ideologies' (Motion and Weaver, 2005: 64). Miskimmon et al. (2013: 16-17) describe discourses as communicative acts that 'are never quite fixed' and thus create 'space for politics and contestation'. Consequently, we characterize discourse as competitive evidence environments where strategic communicators compete for sovereignty over (problem/issue) definition and resolution. We assume that within competitive evidence environments, the quality of strategic communication is a key criterion for its influence - in particular its influence on professional journalism and media coverage with which NGOs also execute influence on political decision makers. Meyer and Sangar (2014: 9) for instance state that 'on average, NGOs have a growing importance as sources of information and framing in the news coverage of armed conflicts' (similarly also Fenton, 2009).

Thus, the communicative quality of NGOs' strategic communications determines the media-related success they can have - for example, why and how the media adopt an NGO's communication input, its views, or its frames. As a result, Baumgartner and Leech (1988: 134) explicate that the question 'should not be whether interest groups are ever influential, but when, why, and to what extent they are powerful on what types of issues' (likewise Fröhlich and Rüdiger, 2006). For instance, the few studies that focus on the strategic communication of NGOs detect that their strategies, tactics, and levels of success vary significantly depending on different (political) interests or external factors like particular issues or topics (Powers, 2014; Schwarz and Fritsch, 2014; Tkalac and Pavicic, 2009; Voss, 2007). Furthermore, research shows that some of those differences depend on particular variables such as the type or size of NGOs (e.g. Fenton, 2009; Van Leuven and Joye, 2014).

NGOs are considered objective purveyors of information who per se enjoy a special legitimacy and reliability (Murdie and Peksen, 2014). This, however, does not relieve them from the necessity of providing excellent information and communication material if they want to successfully compete in public discourse with other strategic actors and 
NGOs over the 'power to define'. Moreover, NGOs are not only providers of information but also groups with a vested interest in certain political outcomes. As such, they are strategic communicators who may sometimes have an interest in seeming more certain than they really are, in obscuring their source of information, etc. According to Keck and Sikkink (1999), they deploy particular tactics to reach their goals. The authors define four types of tactics, amongst them the tactic 'information politics' ${ }^{2}$ This tactic represents the generation of information and its dissemination through influential media which are essential partners in those information politics (p. 96).

In their original work, Keck and Sikkink (1998) clearly state that 'credibility' is one of three key characteristics of successful information politics of NGOs, activists, and advocacy networks (the other two characteristics being speed and drama). A meta-analysis of the effects of persuasive messages (O'Keefe, 1998: 67-71) has shown that both the credibility of a source and the persuasiveness of a source's message increase when it contains evidence. Similarly, Fröhlich and Jungblut (2016) have shown elsewhere that - on an aggregated level - the share of texts containing evidence is correlated to the share of news articles with a reference to the NGO. Hence, we assume that the provision and indication of evidence (such as proven eyewitness accounts from several independent sources or scientific research) contribute to the credibility, plausibility, reliability, and authenticity of statements and thus increases the probability that a communicative act will be considered relevant, meaning it gets selected and further disseminated (by journalists, for instance). As such, evidence contributes to the establishment of NGOs as reliable and legitimate sources in public discourse on war and armed conflict as well as on conflict analysis in general. Evidence, then, can be seen as an indicator of mediarelated effectiveness of persuasive messages. Hence, we consider evidence to be a key construct when it comes to successfully constituting 'facts' instead of 'factoids' ${ }^{3}$ This study therefore analyzes the formation and indication of 'evidence' - Price (1998) refers to 'the burden of proof' - as a key variable for the construction of 'reality' through NGOs' media-related strategic communication in the field of war and armed conflict.

Within the scope of our study, we understand evidence to be a key performance criterion of the accuracy and credibility of conflict communication and define 'evidence' as 'the available body of facts or information indicating whether a belief or proposition is true or valid'. ${ }^{4}$ Against this backdrop, the application and provision of evidence provided by NGOs when making factual claims in their strategic communication is seen as a means of adopting discursive strategies of 'truth' - in our case 'truth' on war and armed conflict. Thus, we consider the provision of 'evidence' firstly as a measurable (existent/ non-existent) component of those discursive truth strategies and therefore secondly as a criterion for the success of NGOs' media-related strategic communication. We thirdly assume that the success of NGOs' strategic communication can be measured in terms of media resonance. These three assumptions represent the basic theoretical component of our later operationalization. In the following, we briefly describe the connectivity of this component to theoretical approaches of excellence and best practice in PR. The aim is to further emphasize the theoretical and practical significance of evidence for the success of persuasive strategic communication.

As per Stacks' (2002: 22) definition of PR as the 'management of credibility', we understand the application and provision of evidence provided by NGOs in communication on 
war and armed conflict as an integral component of their PR activities. This allows us to not only understand 'evidence' as a general key performance criterion of accuracy and credibility of conflict communication but also as a key performance criterion described in normative PR theory as a characteristic of excellence in strategic communication (e.g. Hon and Grunig, 1999; Seo et al., 2009). The following six particularly relevant criteria of 'excellent PR' demonstrate the connectivity of our concept of 'evidence' to existing theory about 'excellent PR':

1. Morgan and Hunt (1994: 32) consider the production of "commitment and trust ... providing resources that are superior to the offerings of alternative partners' and 'communicating valuable information' to be key characteristics of excellent strategic PR. We assume that strategic communication can attain these particular characteristics of excellence by providing information based on evidence.

2. Studies show that effective strategic communication is dependent on the formation of relationships (e.g. Ledingham and Bruning, 2000), which requires communicative 'access and openness' (Hon and Grunig, 1999: 14-15; see also Grunig et al., 2002; Seo et al., 2009) - especially during crises. Within this scenario, the attachment to truth is central for effective strategic communication. We assume that evidence is an important requirement for the emergence of accessibility, openness, relationship building, and truth (Motion and Leitch, 2009).

3. The ability to convey legitimacy to a strategic communicator's cause and objective represents another characteristic of excellent PR (Grunig, 1992: 510). We assume that this can be achieved by providing evidence.

4. With Thrall et al. (2014) we argue that the creation of "newsworthy and compelling information for both media and public audiences' is an important prerequisite for strategic communicators to win attention competitions. We assume that regularly offering evidence is an indicator for newsworthiness and compelling information.

5. Another normative approach to excellent PR is the ideal model of PR as 'twoway symmetrical' communication. According to Grunig (2001), this PR model exercises a dialog with target groups; it 'seeks to create and maintain relationships that balance self-interest with the interests of others' (Murphy, 2000: 448). We consider the indication and provision of evidence in strategic communication as a kind of contextualization that can enable dialog and facilitate discussion. Consequently, we assume that evidence is an indicator of the two-way symmetrical model of strategic communication.

6. A classic normative component of the 'terms and conditions' of excellent PR, finally, is the adaptation of PR content to the media logic (see Maltby, 2015). For instance, not only do journalists tend to present information as relatively certain (Struckmann et al., 2012) even if it often is not (e.g. Stocking, 1999). Prospect theory assumes that political decision makers also prefer certainty-framing to uncertainty-framing (Quattrone and Tversky, 1988; Tversky and Kahneman, 1992). We consider the provision of evidence to be an important means of certainty-framing. As such, evidence once more increases the chance of persuasive strategic information being selected by journalists (and political decision makers) 
for further dissemination and discussion. Figure 1 gives a summarized overview of the six selected excellence criteria which are particularly suitable to demonstrate the connectivity of our concept of 'evidence' and the current theory of excellence in strategic communication.

Before we deduce specific research questions from our theoretical discussion, we need to clarify an important point: the provision of evidence in persuasive strategic communication (from propaganda to other forms of strategic communication) does not necessarily mean that the evidence given is 'real' or 'true' in the sense of veracity (really existing). As we pointed out above, strategic communicators do have a vested interest in certain political outcomes. NGOs are not an exception to this. They, too, may sometimes have an interest in seeming more certain about their evidential claims than they really are. Like every other strategic communicator, they may frame their communication with partial or slanted evidence. This is just another tactic of 'information politics'. We consider the provision of information about the epistemological status of evidential claims (evidential claims that are presented as either [rather] certain or uncertain in strategic communication) a criterion of its quality: to communicate an evidential yet uncertain claim while proactively admitting to uncertainty concerning this claim is considered a persuasive strength and contributes to a communicator's general credibility. To admit uncertainty also distinguishes credible information from propaganda (propaganda usually does not admit to uncertainty). Here, NGOs and political actors/entities can improve the factual basis and character of their communication on war and armed conflict by admitting uncertainty where it exists. In doing so, they avoid the impression that they somehow deal with factoids. It also contributes to NGOs' general credibility and to their expert role, particularly in today's post-factual/post-truth era.

Our approach is not to verify the actual truth and validity of given evidence in strategic texts. We instead argue that (persuasive strategic) information in general receives higher credibility (and thus has possibly also stronger effects) with respective target groups when it is backed up by additional evidential information. This is what can be analyzed with quantitative empirical content analysis (evidence existent vs non-existent). The actual validity of given evidence requires qualitative approaches of analysis on a case-by-case basis if it can be verified at all. In a worst-case scenario, this means that strategic communication that provides convincing but 'truthless' evidence can be very effective - as we can learn, for instance, from Russian President Putin's or US President Trump's strategic communication and propaganda. In this case, normative PR theory indeed would not talk of 'excellent strategic communication'. Practitioners, however, probably would. Apart from this, the question of the real success of Trump's and Putin's strategic communication could be vehemently argued. It could be considered successful if their strategies, tactics, factoids and lies were not discussed in public discourse.

\section{Research questions}

Our main research question is: 'Does NGOs' strategic communication on war and armed conflict adopt discursive strategies of "truth" by providing evidence, and, if so, to what degree?' The study addresses this question using a twofold research strategy: Firstly, it 


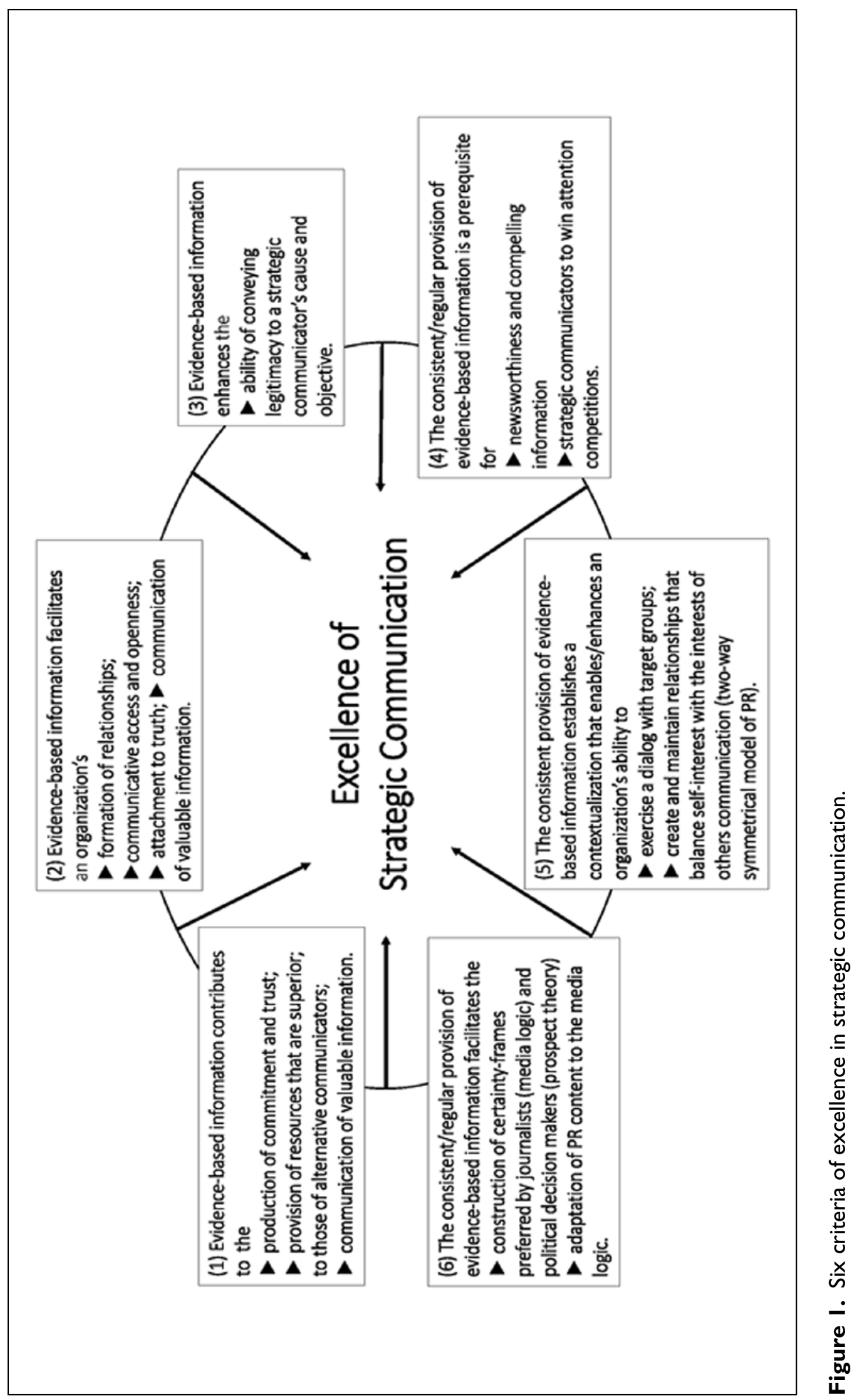


seeks to analyze how transparently NGOs communicate the sources of their 'evidential claims'. ${ }^{5}$ Secondly, the study aims to examine if and how NGOs communicate the epistemological status of information on war and armed conflict. Since NGOs' communication strategies and their success vary depending on the type or size of NGOs (see above), we decided to differentiate between local and transnational NGOs (TnNGO). ${ }^{6}$ Furthermore, Meyer and Sangar (2014: 4) state that differences between local NGOs and large transnational NGOs - the authors speak of 'the usual suspects' - remain largely unexplored.

\section{(I) Transparency of sources of evidence}

Our study addresses the question of whether NGOs' communications on war and armed conflict provide sufficient evidence to support their evidential claims. As a first criterion, we understand sources of evidence to be references to where evidential claims stem from. Here, we analyze who (person or institution) is mentioned as the author, and the origin ${ }^{7}$ of the respective evidential claims. Based on this understanding, our study investigates how the validity of evidence is constituted in NGOs' strategic communication on war and armed conflict. As a result, we analyze if authors and origins are provided as sources of evidence and which kinds of authors and origins are relied upon more frequently. The first research question and its subset of questions are:

RQ1: How transparently do NGOs communicate sources of evidence through references to authors and/or origins of their presented evidential claims on war and armed conflict?

RQ1a: Does NGOs' strategic communication refer to authors (political entities, media, military, etc.) of evidential claims, and what kind of origins (media news, intelligence report, research, etc.) are referred to?

RQ1b: Do local NGOs and TnNGOs differ with regard to the transparency of the authors and origins of the provided evidential claims, and, if so, how?

\section{(2) Epistemological status of evidential claims}

Additionally, we analyze how often epistemological statuses are used to express the validity of evidential claims on war and armed conflict and then evaluate how these statuses are communicated. We do so by applying a semantic differential in order to distinguish between two kinds of statuses, namely, evidential claims that are presented as either (rather) certain or uncertain. The second research question and its subset of questions are:

RQ2: Do NGOs communicate the epistemological status of their evidential claims on war and armed conflict, and, if so, to what degree?

RQ2a: Are the evidential claims provided in NGOs' strategic communication characterized by attributing an epistemological status, and, if so, which kind of epistemological status (certain or uncertain) is applied? 
RQ2b: Does the attribution of (the two different) epistemological statuses to evidential claims differ between local NGOs and TnNGOs, and, if so, how?

\section{Methodology}

Our study uses data from computer-assisted content analysis conducted with the help of $\mathrm{JAmCAT}^{8}$ software (Baden and Stalpouskaya, 2015). Thus, we were able to examine a wide array of texts stemming from 63 different NGOs, of which 31 are transnational and 32 local NGOs (see Appendix 1). The respective sample has been constructed based on extensive web research and in close collaboration with INFOCORE'S conflict experts, ${ }^{9}$ its associated stakeholder network, ${ }^{10}$ and its advisory board. ${ }^{11}$ For the purpose of this study, we decided to concentrate on NGOs that are engaged in our three conflict regions and whose texts have been distributed either in English, German, or French. ${ }^{12}$ Fröhlich (2017) explains that and why activists' and NGOs' communication increasingly makes use of the internet. This shows why we considered it appropriate to gather the research material for our study from NGO websites and their online archives. This includes NGOs' official press releases provided in archives of their online press rooms as well as the media-like communication means of NGOs, meaning our research material differs significantly both in form (reports, press releases, speeches, journals, etc.) and overall length (ranging from 27 to 158,415 words). We relied on the INFOCORE conflict experts and the conflict descriptions by the United Nations, BBC, and Timelines of History (http://timelines.ws/) to compose the specific periods of investigation (see Table 1). Overall, we gathered 16,232 texts that were then turned into machine-readable data. ${ }^{13}$ Table 1 provides an overview of this study's overall sample.

These texts were analyzed with JAmCAT and Python scripts. To identify authors and origins of sources of evidence (RQ1) and to measure reference to epistemology (RQ2), we relied on a dictionary that was created as part of the INFOCORE project. It operationalizes around 3,800 different semantic concepts, each expressing semantic ideas such as actors, places, adjectives, or actions. Herein, each concept is connected to expressions that indicate its application in a text in the different languages included in this research project. ${ }^{14}$ This procedure enables a high level of comparability across different cases and languages. To guarantee the reliability of the automated coding, each language included in the dictionary was tested for precision and recall by trained coders. Precision is the share of codings found by the computer that was also found manually, while recall is the share of codings that was identified by the coders and also found automatically (Sheafer et al., 2014). The sample used was 3,000 sentences per language. Overall, the dictionarywide level of correspondence reached a satisfying level with no value lower than .85 (see Table 2). From this dictionary, we selected and grouped those concepts that either characterize different groups of authors or origins (RQ1) or that refer to the certainty or uncertainty of a claim (RQ2).

The origins and sources of evidential claims were identified with the help of a Python script looking for specific expressions that signalize a claim is attributed to a source/origin. These expressions were then collected with the aid of an annotated corpus of sampled material. The reliability of this script was tested for false positives as well as false negatives for all three languages. Table 3 contains some examples of the expressions used to identify the origins and authors (complete list upon request) (see Appendix 2b). 
Table I. Overview of the applied sample.

\begin{tabular}{|c|c|c|c|}
\hline Conflict cases & Type of NGO & Number of texts & Periods of investigation \\
\hline \multicolumn{4}{|l|}{ Great Lakes Region Africa } \\
\hline Burundi & Local NGOs & 669 & $2010-2014$ \\
\hline Burundi & TnNGOs & 257 & \\
\hline $\begin{array}{l}\text { Democratic Republic of } \\
\text { Congo (DRC) }\end{array}$ & Local NGOs & 471 & $2012-2014$ \\
\hline $\begin{array}{l}\text { Democratic Republic of } \\
\text { Congo (DRC) }\end{array}$ & TnNGOs & 1,529 & \\
\hline \multicolumn{4}{|l|}{ Western Balkans } \\
\hline Kosovo & Local NGOs & 235 & $2010-2014$ \\
\hline Kosovo & TnNGOs & 293 & \\
\hline Macedonia & Local NGOs & 188 & $2011-2014$ \\
\hline Macedonia & TnNGOs & 33 & \\
\hline \multicolumn{4}{|l|}{ Middle East } \\
\hline Israel/Palestine & Local NGOs & 4,144 & $2006-2014$ \\
\hline Israel/Palestine & TnNGOs & 3,072 & \\
\hline Syria & Local NGOs & 3,934 & $2011-2014$ \\
\hline Syria & TnNGOs & $\mathrm{I}, 407$ & \\
\hline Total & Local NGOs & 9,641 & \\
\hline Total & TnNGOs & 6,591 & \\
\hline $\mathbf{N}$ & & 16,232 & \\
\hline
\end{tabular}

Table 2. Reliability analysis for automated coding.

\begin{tabular}{llc}
\hline Language & Precision & Recall \\
\hline English & 0.94 & 0.96 \\
French & 0.86 & 0.96 \\
German & 0.93 & 0.92 \\
\hline
\end{tabular}

Table 3. Examples of expressions that indicate the occurrence of an author or the origin of an evidential claim.

\begin{tabular}{lll}
\hline $\begin{array}{l}\text { English expressions } \\
\text { (selection) }\end{array}$ & $\begin{array}{l}\text { German expressions } \\
\text { (selection) }\end{array}$ & $\begin{array}{l}\text { French expressions } \\
\text { (selection) }\end{array}$ \\
\hline 'as reported by' & 'nach Angaben von' & 'selon' \\
'in agreement with' & 'Stellungnahme' & 'suivant' \\
'as stated in' & 'zufolge' & 'conformément à' \\
\hline
\end{tabular}

All sentences that contained these expressions were extracted, along with an indicator that linked the extracted sentences to the texts from which they stem. We subsequently applied the dictionary to identify who was mentioned as the 'author' of the evidential claim (person, institution), and what 'origin' of claims (annual report, speech, research 
Table 4. Author and origins of sources of evidence identified in NGO strategic texts.

\begin{tabular}{ll}
\hline Author & Origins \\
\hline NGOs (others and self-reference) & Personal statement ${ }^{15}$ \\
Media & Report \\
Military (representatives) & Research \\
Political actors & (Press) conference \\
& Speech \\
\hline
\end{tabular}

paper, etc.) was referred to. Table 4 shows the different groups of actors and origins that were operationalized based on the dictionary and identified in the texts.

To examine how transparently the epistemic statuses of the provided evidential claims were communicated, we collected all semantic concepts that expressed the 'certainty' or 'uncertainty' of a given piece of information. We created these two groups of epistemological statuses because in a text they almost demand further justification as to why something is certain (e.g. mentioning a reliable source) or uncertain (e.g. conceding that concrete proof does not [yet] exist). We consider this form of 'justification' to be an indicator of the application of evidence. ${ }^{16}$ We subsequently analyzed the occurrence of the two groups of (semantic) concepts (certainty and uncertainty) in the different texts to determine how often evidential claims are described with either kind of epistemological status (see Appendix 2a).

\section{Results}

The first research question analyzes how transparently NGOs communicate authors (politicians, academics, media/journalists, etc.) and origins (reports, press conferences, etc.) of their sources of evidence. In this process, we first examined the number of references to sources of evidence (authors and/or origins; multiple response) (RQ1a). Out of all 16,232 texts, 53 percent mention a reference to sources of evidence to support their claims, while the rest contain claims but do not offer any supporting source of evidence for those claims. A reference specifically to an author of a given piece of evidence can be found in 38 percent of all texts. The most dominant kind of authors is the NGOs themselves (31\%; self-reference and/or other NGOs, which refers to the 'expert' status of NGOs), followed by political actors $(30 \%)$, and military representatives (14\%). Media, with only 5 percent, seems to play a dispensable role for NGOs as an author of evidence in war and armed conflict. This may be due to the fact that NGOs prefer to prove their own powers of investigation (with political actors and the military, for example) than to rely on media investigations - especially considering that the media has normally published its (exclusive) facts already, meaning NGOs would be dealing with 'water under the bridge'. In this regard, NGOs see themselves as more of a source for the media rather than the other way around. In addition, the minor relevance of the media as an author/ source for NGOs may be a consequence of the actual circumstances on the ground: In most cases, NGOs are often closer to the conflict zones than journalists, or they remain there while journalists move on to more pressing conflict zones. 
Table 5. Number of texts with references to origins of sources of evidence (\%).

\begin{tabular}{ll}
\hline Origins & $\begin{array}{l}\text { Number and share of texts containing } \\
\text { reference to origin of evidence }(N=16,232)\end{array}$ \\
\hline Personal statement & $5,546(34)$ \\
Report & $1,313(8)$ \\
Research & $415(3)$ \\
(Press) conference & $210(1)$ \\
Speech & $118(1)$ \\
\hline
\end{tabular}

Table 6. Comparison of local NGO and TnNGO references to sources of evidence (authors and origins) (\%).

\begin{tabular}{llll}
\hline & $\begin{array}{l}\text { TnNGOs } \\
(n=6,59 I)\end{array}$ & $\begin{array}{l}\text { Local NGOs } \\
(n=9,64 I)\end{array}$ & $\begin{array}{l}\text { Total } \\
(N=16,232)\end{array}$ \\
\hline $\begin{array}{l}\text { Number of texts with reference to } \\
\text { sources of evidence (share) }\end{array}$ & $3,85 \mathrm{I}(58)^{*}$ & $4,783(50)^{*}$ & $8,634(53)^{*}$ \\
$\begin{array}{l}\text { Number of texts with reference to } \\
\text { authors (share) }\end{array}$ & $2,900(44)^{* * *}$ & $3,262(34)^{* * *}$ & $6,162(38)^{* *}$ \\
$\begin{array}{l}\text { Number of texts with reference to } \\
\text { origins (share) }\end{array}$ & $2,957(45)^{* * * *}$ & $3,389(35)^{* * *}$ & $6,346(39)^{* * * *}$ \\
\hline
\end{tabular}

$*_{p}=.000, \chi^{2}=122.233, \mathrm{phi}=.087 ; * * p=.000, \chi^{2}=171.746, \mathrm{phi}=.103 ; * * * p=.000, \chi^{2}=155.083$, phi $=.010$.

The origin of a given piece of evidence was referred to in 39 percent $(6,346)$ of the texts containing evidence. The most frequently coded origin was 'personal statement' (34\%) followed by 'report' (8\%). All other forms of origin are of minor relevance (see Table 5). This either means that NGOs have a fixed set of experts or witnesses that they cite regularly or that they do not reveal from which (kind of publication) a quote stems. Both possibilities might indicate a high level of 'opportune witnesses' (Hagen, 1993) in NGO's strategic communication. Either by calling specific experts - knowing what they might have to say - or by selecting specific quotes without revealing where exactly they come from, NGOs might be using experts to support a claim that expresses their own perspective on a given conflict situation. This reflects the results from the analysis of authors of sources of evidence. Here, NGOs most often used claims that were backed up by themselves or other NGOs.

RQ1b addresses the differences between local NGOs and TnNGOs concerning the transparency of the sources of evidence. A comparison of the number of texts containing a reference to sources of evidence (authors and/or origin; multiple response; see Table 6) shows, firstly, that only a minority of texts provide specifications on authors and origins. Secondly, it shows that TnNGOs mention the sources of evidence (authors and/or origin) significantly more often than local NGOs. Again, while the effects are highly significant, the effect size is rather small.

The second research question examines whether NGOs communicate the epistemological status of evidential claims they provide on war and armed conflict. We analyzed 
if and how (often) NGOs make reference to epistemological statuses (RQ2a). Overall, we identified a reference to an epistemological status in 77 percent $(n=12,563)$ of all texts $(n=16,232)$, which means that still around one in four texts contains evidential claims without any epistemological reference. Furthermore, in general, NGOs slightly favor the status 'certainty' of information (65\% of texts) to the status 'uncertainty' $(59 \%)$ (multiple response set) and thus, more often than not, state what they have proved to be true rather than providing information about which they are uncertain. In terms of the effectiveness of strategic communication, this might represent an endeavor to increase the probability of being heard and picked by providing definite information.

Our data reveals that TnNGOs provide significantly more evidential claims that are characterized with an epistemological status (RQ2b): 82 percent of the communicated messages of TnNGOs make reference to epistemology, whereas 75 percent of local NGOs do so. The effect size is small, but the difference is highly significant ( $\mathrm{phi}=.081$, $p=.00)$. The same pattern can be observed when focusing on references to certainty (71\% TnNGOs' texts; $61 \%$ local NGOs' texts) and uncertainty (66\% TnNGOs' texts; $54 \%$ local NGOs' texts). An explanation could be that the bigger TnNGOs might have more (financial, human) resources available for (more) investigation into the proofs (certainty) of their conflict-related evidential claims. To admit that information is uncertain is risky from the perspective of successful media-related persuasive communication. It seems that local NGOs are less willing to take this risk and instead more often forgo references to any uncertain information compared to TnNGOs.

\section{Discussion and future prospects}

Our results reveal that the normative quality of NGOs' strategic communication - judged by the indication of sources and the epistemological statuses of their (NGOs') evidential claims - needs further professionalization: 47 percent of all texts do not provide any source specification. This high share is disappointing. Following the normative approach, it is obvious that NGOs writing on war and armed conflict therefore still need to improve the factual character of their communication and thus to avoid the impression that they are dealing with factoids. Furthermore, the data shows that NGOs in the field of war and armed conflict only slightly more often state what they have proved to be true rather than providing information which they are uncertain about (65\% vs 59\%). While this difference seems to be marginal in a percentage-based perspective, it expresses a difference of over 900 texts within the sample.

With respect to this, we can corroborate the assumption that the NGOs under investigation adapt their strategic communication of evidence to media logic as well as to the logic of the political system; as explained, both prefer certainty-framing to uncertaintyframing. Thus, the analyzed NGOs consider normative criteria for excellent PR and effective strategic communication. However, since we know that strategic communicators clearly prefer to dodge uncertainty and other forms of peradventure (Sheafer and Gabay, 2009), the share for uncertainty here is surprisingly high. It appears as if the NGOs under investigation perform as strategic communicators and simultaneously also as 'experts'. According to Jowett and O'Donnell (2012), experts are said to prefer uncertainty in their communication. The fact that the most dominant kind of source for 
evidential claims on war and armed conflict is NGOs themselves further underlines their expert status. Whether or not this concurrently undermines the NGOs' role as professional strategic communicators cannot be easily answered. Strictly speaking, self-references are not really a form of independent evidence and as such are not a sign of excellent strategic communication. Self-reference, however, allows NGOs to promote themselves as experts in the field. Thus, the strategic communication of NGOs in the field of war and armed conflict seems to be caught between two stools - on the one hand, that of the strategic communicator and, on the other hand, that of the expert.

This particularly applies to TnNGOs: firstly, their texts in general contain higher shares of both epistemic statuses (certainty/uncertainty). Secondly, their texts also mention sources of evidence significantly more often than local NGOs' texts. TnNGOs might have more (financial/human) resources available than local NGOs for investigation into the proofs of their war and conflict-related claims and thus find it easier to align their communication with normative requirements of effective/excellent strategic communication. As a result, they might also possess more assertiveness than local NGOs which provides them with more aplomb when dealing with uncertainty and relying on their role as expert. Since many TnNGOs target quality Western news media and therefore need to fit with their normative expectations, though, resources might only be part of the explanation. However, concerning different types of NGOs, further research is needed to investigate in more detail the particularities of, for example, think tanks and/or research NGOs engaged in different conflicts. Both types, local and TnNGOs, refer mostly to their own data, which could result in lower shares of references to epistemology.

Concerning the transferability of normative approaches of excellent strategic communication to the communicative behavior of NGOs specialized in the field of war and armed conflict, we draw the following conclusion: the normative criteria of excellence in PR executed above have not been applied sufficiently by the NGOs under investigation. In her study on the communication of environmental NGOs, Voss (2007) suggests that these normative approaches might not be suitable for the analysis of all NGOs. Rather, she describes environmental NGOs' communication as a means to make demands, request changes, seek confrontation with existing perspectives and establish the image of a relentless fighter for a good cause. This, we think, cannot be stated for NGOs acting in the field of war and armed conflicts. Here, sensitive issues such as peace keeping and de-escalation require a high degree of empathy, caution, cooperation, and the willingness to compromise.

Additionally, whereas environmental NGOs are part of a continuous struggle of a relentless 'David' against a seemingly invincible 'Goliath', NGOs acting in the field of war and violent conflict are much more on a par with the political actors at the centers of power. Also, while for environmental NGOs, openness to dialogue and compromises are often regarded as a weakness or even a betrayal of ideals, these activities are an elementary constituent of the political work of NGOs acting in the field of war and armed conflict. They thereby express strength rather than weakness and demonstrate their diplomatic and conciliatory potential. Against this backdrop, the application of the suggested normative approach therefore seems crucial and expectable for NGOs acting in this precarious field. Finally, whereas Voss suggests that environmental NGOs try to create media attention through a confrontational communication strategy (see also Holtzhausen, 
2007), NGOs acting in the field of war and armed conflicts (dialogue, mediation, education, neutrality, etc.) instead need/seek to interact with political decision makers on a non-confrontational basis. Here, one can assume, too much media attention might even be counterproductive.

Against this backdrop, we are convinced that our results can provide potential for the professionalization of NGOs' strategic communication in the field of war and armed conflicts. We of course cannot elaborate in detail here on communicative advice on the basis of our study. This will be reserved for another, more application-oriented publication. As a general rule, we state here that more awareness and provision for the epistemological status of evidential claims about war and armed conflicts and the transparency of authors and origins (where possible and applicable!) would be a first step in the right direction. Furthermore, our content-analytical approach, which has been developed for the purpose of this study, might contribute to the further development of conflict analysis in general, for instance when deciding on the reliability and verification of NGO information on the basis of big-data scenarios. Finally, why NGOs verbalize which kind of contents depends on NGOs' strategic considerations, their cultural perceptions and conventions, and the salience of observations. Against this backdrop, it would be worthwhile to investigate the actual purposes NGOs pursue with PR. This could provide interesting insights into the application of different models of strategic communication and their suitability for this area. These aspects require survey data (see Meyer et al., 2018; see also Adolphsen, 2012). Thus, the next step will be to interlace content analysis with survey data. Another interesting question for research should deal with the fact that NGOs not only endeavor to gain media and public attention with routine publicity but also with staged events. This also applies to NGOs in the field of war and armed conflict(s). It therefore would be interesting to compare epistemological statuses of their routine strategic communication with that of their 'staged PR-events'. Conclusion: there's still a lot to be done.

\section{Funding}

The author(s) disclosed receipt of the following financial support for the research, authorship, and/ or publication of this article: The work for this special issue was funded by the EU's FP7 programme under the Grant Agreement No 613308 for the INFOCORE project (www.infocore.eu).

\section{Notes}

1. We consider the term 'strategic communication' a synonym for public relation. On the basis of a combination of two existing definitions, we define the term as the purposeful and deliberate use of communication by an organization to fulfill its mission and/or to reach set goals (Hallahan et al., 2007: 3; Holtzhausen and Zerfass, 2013: 74). For a more detailed explanation, see Fröhlich and Jungblut (2015).

2. Three further types of tactics: 'symbolic politics' (symbols, narratives, etc.), 'leverage politics' (alliances with other stronger actors), and 'accountability politics' (holding actors to promises and avowed principles) (Keck and Sikkink, 1999: 95-98).

3. Factoid in the sense of half-truth. In our particular understanding here, claims which are missing the provision of evidence. See also The Oxford English Dictionary: 'Noun: An item of information accepted as a fact, although not (or not necessarily) true; spec. an assumption or speculation reported and repeated so often as to be popularly considered true; a simulated or 
imagined fact.' Available at: http://www.oed.com/view/Entry/67511?redirectedFrom=factoid \#eid (accessed 5 August 2017).

4. Available at: http://www.oxforddictionaries.com/de/definition/english/evidence(accessed 5 August 2017); see also McCroskey (1967).

5. We define evidential claims as factual 'statements about the state of the world ... (that) provide selected information about current events, recall specific pasts and project expected future developments' (Baden, 2014: 2).

6. Local NGOs 'focus on only one country or region' whereas transnational ones 'conduct activities in geographically separated zones of conflict, rather than those who simply claim to have global aspirations' (Meyer and Sangar, 2014: 6).

7. On what occasion and/or in what form has information been provided?

8. Available at: http://jamcat.mscc.huji.ac.il/accounts/login/?next=/ (accessed 5 August 2017).

9. Available at: http://www.infocore.eu/expert-directory/ (accessed 15 June 2016).

10. Available at: http://www.infocore.eu/consortium/associated-stakeholder-network/ (accessed 15 June 2016).

11. Available at: http://www.infocore.eu/consortium/advisory-board/ (accessed 15 June 2016).

12. This is due to the language expertise necessary in the process of creating the script for the extraction of the origins of evidential claims.

13. Due to technical restrictions with the PDF format, we were unable to convert all texts into machine-readable data.

14. For more details, see Baden and Stalpouskaya (2015).

15. For instance, in the sense of Hagen's (1993) concept of 'opportune witnesses' and Kepplinger's 'instrumental actualization' (e.g. Kepplinger et al., 1991), which were both developed with regard to journalists' usage of opportune expert citations in cases of (considerable) uncertainty.

16. Expressions used to identify these concepts can be delivered upon request.

\section{References}

Adolphsen M (2012) Communication Strategies of Governments and NGOs: Engineering Global Discourse at High-Level International Summits. Wiesbaden: Springer VS.

Baden C (2014) Constructions of Violent Conflict in Public Discourse: Conceptual Framework for the Content \& Discourse Analytic Perspective (within WP5, WP6, WP7, \& WP8), INFOCORE Working Paper 2014/10. Available at: http://www.Infocore.eu/wp-content/ uploads/2016/02/Conceptual-Paper-MWG-CA_final.pdf (accessed 15 June 2016).

Baden C and Stalpouskaya K (2015) Common Methodological Framework: Content Analysis. A Mixed-Methods Strategy for Comparatively, Diachronically Analyzing Conflict Discourse. INFOCORE Working Paper 2015/10. Available at: http://www.infocore.eu/wp-content/ uploads/2016/02/Methodological-Paper-MWG-CA_final.pdf (accessed 15 June 2016).

Baumgartner F and Leech B (1988). Basic Interests: The Importance of Groups in Politics and in Political Science. Princeton, NJ: Princeton University Press.

Bloodgood EA (2011) The interest group analogy: International non-governmental advocacy organisations in international politics. Review of International Studies 37: 93-120.

Curtin PA (2016) Exploring articulation in internal activism and public relations theory: A case study. Journal of Public Relations Research 28: 19-34. DOI: 10.1080/1062726X.2015.1131696.

Fenton N (2009) New Media, Old News: Journalism and Democracy in the Digital Age. Los Angeles: Sage.

Fröhlich R (2014) Strategic Communication's Contributions and Roles in the Media's Dynamic Construction and Contestation of Conflict Discourse: Theoretical/Conceptual Framework for Work Package 6: 'Strategic Communication'. Available at: http://www.infocore.eu/wpcontent/uploads/2016/02/Conceptual-Paper-WP6_final.pdf (accessed 15 June 2016). 
Fröhlich R (2017) The changes in modern activist communication: Theoretical insights into new challenges for public relations. In: Duhé SC (ed.) New Media and Public Relations, 3rd edn. New York: Peter Lang, 185-197.

Fröhlich R and Jungblut M (2015) INFOCORE Definitions: 'Strategic Communicator/ Communication'. Munich: Ludwig-Maximilians-Universität München. Available at: http:// www.infocore.eu/results/definitions/ (accessed 15 June 2016).

Fröhlich R and Jungblut M (2016) Effective and coherent media-related communication during war and armed conflicts: Policy brief for political actors and NGOs. INFOCORE Work Package 'Strategic Communication'. Available at: http://www.infocore.eu/wp-content/ uploads/2017/02/D6.3_Policy-Brief_Strategic_Communication.pdf (accessed 15 June 2016).

Fröhlich R and Rüdiger B (2006) Framing political public relations: Measuring success of political communication strategies in Germany. Public Relations Review 32: 18-25.

Gershkoff A and Kushner S (2005) Shaping public opinion: The 9/11-Iraq connection in the Bush administration's rhetoric. Perspectives on Politics 3(3): 525-537. DOI: 10.1017/ S1537592705050334.

Grunig JE (2001) Two-way symmetrical public relations: Past, present, and future. In: Heath RL (ed.) Handbook of Public Relations. Thousand Oaks, CA: Sage, 11-30.

Grunig LA (1992) Activism: How it limits the effectiveness of organizations and how excellent public relations departments respond. In: Grunig JE (ed.) Excellence in Public Relations and Communication Management. Hillsdale, NJ: Lawrence Erlbaum, 503-530.

Grunig LA, Grunig JE and Dozier DM (2002) Excellent Public Relations and Effective Organizations: A Study of Communication Management in Three Countries. Mahwah, NJ: Lawrence Erlbaum.

Hagen LM (1993) Opportune witnesses: An analysis of balance in the selection of sources and arguments in the leading German newspapers' coverage of the census issue. European Journal of Communication 8(3): 317-343.

Hallahan K et al. (2007) Defining strategic communication. International Journal of Strategic Communication 1(1): 3-35.

Holtzhausen D (2007) Activism. In: Toth EL (ed.) The Future of Excellence in Public Relations and Communication Management. Mahwah, NJ: Lawrence Erlbaum, 357-380.

Holtzhausen DR and Zerfass A (2013) Strategic communication: Pillars and perspectives on an alternate paradigm. In: Sriramesh K et al.(eds) Current Trends and Emerging Topics in Public Relations and Communication Management. New York: Routledge, 283-302.

Hon LC and Grunig JE (1999) Guidelines for Measuring Relationships in Public Relations. Gainesville, FL: Institute for Public Relations.

Jowett GS and O'Donnell V (2012) Propaganda and Persuasion. Thousand Oaks, CA: Sage.

Keck ME and Sikkink K (1998) Activists beyond Borders: Advocacy Networks in International Politics. Ithaca, NY: Cornell University Press.

Keck ME and Sikkink K (1999) Transnational advocacy networks in international and regional politics. International Social Science Journal 51(159): 89-101. DOI: 10.1111/1468-2451.00179.

Kepplinger HM, Brosius H-B and Staab JF (1991) Instrumental actualisation: A theory of mediated conflicts. European Journal of Communication 6(3): 263-290.

Ledingham JA and Bruning SD (2000) Public Relations as Relationship Management: A Relational Approach to the Study and Practice of Public Relations. Mahwah, NJ: Lawrence Erlbaum.

Maltby S (2015) Imagining influence: Logic(al) tensions in war and defence. In: Hjarvard S et al. (eds) The Dynamics of Mediatized Conflicts. New York: Peter Lang, 165-183.

Meyer C and Sangar E (2014) NGOs, Media and Conflict: Conceptual Framework for WP4. Available at: http:/www.infocore.eu/wp-content/uploads/2016/03/infocore-conceptualframework-WP4_NGOs-and-media.pdf (accessed 28 March 2017). 
Meyer CO, Sangar E and Michaels E (2018) How do non-governmental organizations influence media coverage of conflict? The case of the Syrian conflict, 2011-2014 Media, War \& Conflict 11(1): 149-171.

McCroskey JC (1967) The Effects of evidence in persuasive communication. Western Journal of Speech Communication 31: 189-199.

Miskimmon A, O'Loughlin A and Roselle L (2013) Strategic Narratives: Communication Power and the New World Order. New York: Routledge.

Morgan RM and Hunt SD (1994) The commitment-trust theory of relationship marketing. Journal of Marketing 58(3): 20-38.

Motion J and Leitch S (2009) On Foucault: A toolbox for public relations. In Ihlen Ø et al. (eds) Public Relations and Social Theory: Key Figures and Concepts. New York: Routledge, 83102.

Motion J and Weaver CK (2005) A discourse perspective for critical public relations research: Life sciences network and the battle for truth. Journal of Public Relations Research 17: 49-67. DOI: $10.1207 / \mathrm{s} 1532754 x j p r r 1701 \_5$.

Murdie A and Peksen D (2014) The impact of human rights INGO shaming on humanitarian intervention. Journal of Politics 76(1): 215-228.

Murphy P (2000) Symmetry, contingency, complexity: Accommodating uncertainty in public relations theory. Public Relations Review 24: 447-462.

O'Keefe DJ (1998) Justification explicitness and persuasive effect: A meta-analytic review of the effects of varying support articulation in persuasive messages. Argumentation and Advocacy 35: 61-75.

Powers M (2014) The structural organization of NGO publicity work: Explaining divergent publicity strategies at humanitarian and human rights organizations. International Journal of Communication 8: 90-107.

Price R (1998) Reversing the gun sights: Transnational civil society targets land mines. International Organization 52(3): 613-44.

Quattrone G and Tversky A (1988) Contrasting rational and psychological analyses of political choice. American Political Science Review 82(3): 719-736.

Schwarz A and Fritsch A (2014) Communicating on behalf of global civil society: Management and coordination of public relations in international nongovernmental organizations. Journal of Public Relations Research 26(2): 161-183. DOI: 10.1080/1062726X.2013.864242.

Seo H, Kim JY and Yang S-U (2009) Global activism and new media: A study of transnational NGOs' online public relations. Public Relations Review 35: 123-126. DOI: 10.1016/j.pubrev.2009.02.002.

Sheafer T and Gabay I (2009) Mediated public diplomacy: A strategic contest over international agenda building and frame building. Political Communication 26: 447-467.

Sheafer $\mathrm{T}$ et al. (2014). Relative political and value proximity in mediated public diplomacy: The effect of state-level homophily on international frame building. Political Communication 31(1): 149-167. DOI: 10.1080/10584609.2013.799107.

Smith MF and Ferguson DP (2001) Activism. In: Heath RL (ed.) Handbook of Public Relations. Thousand Oaks, CA: Sage, 291-300.

Stacks DW (2002) Primer of Public Relations Research, 2nd edn. New York: The Guilford Press.

Stocking HS (1999) How journalists deal with scientific uncertainty. In: Friedmann S et al. (eds) Communicating Uncertainty: Media Coverage of New and Controversial Science. Mahwah, NJ: Erlbaum, 23-41.

Struckmann S, Steinle T, Biedermann, D et al. (2012) (Dis)covering uncertainty in war journalism: A content analysis of source related uncertainty in the coverage of wars.Paper presented at the 4th ECREA Conference, Istanbul, Turkey. 
Supa DW (2014). The academic inquiry of media relations as both a tactical and strategic function of public relations. Research Journal of the Institute for Public Relations 1(1): 1-15.

Taylor M, Kent ML and White WJ (2001). How activist organizations are using the Internet to build relationships. Public Relations Review 27: 263-284.

Thrall AT, Stecula DA and Sweet D (2014) 'May we have your attention please?!' Human rights NGOs and the problem of global communication. International Journal of Press/Politics 19(2): 135-159. DOI: 10.1177/1940161213519132.

Tkalac A and Pavicic J (2009) Nongovernmental organizations and international public relations. In: Sriramesh K, Verčič D (eds) The Global Public Relations Handbook: Theory, Research, and Practice, 2nd edn. New York: Routledge, 807-821.

Tversky A and Kahneman D (1992) Advances in prospect theory: Cumulative representation of uncertainty. Journal of Risk and Uncertainty 5: 297-323.

Van Leuven S and Joye S (2014) Civil society organizations at the gates? A gatekeeping study of news making efforts by NGOs and government institutions. International Journal of Press/ Politics 19(2): 160-180. DOI: 10.1177/1940161213514615.

Van Leuven S, Heinrich A and Deprez A (2015) Foreign reporting and sourcing practices in the network sphere: A quantitative content analysis of the Arab Spring in Belgian news media. New Media \& Society 17: 573-591. DOI: 10.1177/1461444813506973.

Voss K (2007) Öffentlichkeitsarbeit von Nicht-Regierungsorganisationen. Mittel - Ziele - interne Strukturen (Public Relations of NGOs. Instruments - Aims - Internal Structures). Wiesbaden: VS.

Weick KE (1969) The Social Psychology of Organizing. Reading, MA: Addison-Wesley.

Zoch LM and Molleda JC (2006) Building a theoretical model of media relations using framing, information subsidies, and agenda building. In: Botan $\mathrm{CH}$, Hazleton V (eds) Public Relations Theory II. Mahwah, NJ: Lawrence Erlbaum, 245-271.

\section{Author biographies}

Romy Fröhlich is a full time professor at Ludwig-Maximilians-University Munich. Her research interests include news research (content analysis), gender, (influence of ) PR, and conflict/war \& media. She is co-editor of the Routledge Handbook of Media, Conflict and Security and coordinator of an EU-project on media and war (INFOCORE). She was president of the German Communication Association (DGPuK).

Marc Jungblut is a researcher, lecturer and doctoral student at Ludwig-Maximilians-University Munich. He is a member of the INFOCORE research project, funded by the Seventh Framework Programme of the European Commission. His main research interests are political communication, journalism, war and violent conflicts, framing, news production processes and methodology. 
Appendix I. List of analyzed NGOs.

NGO

Association Burundaise pour la Protection des Droits

Humains et des Personnes Détenues (APRODH)

Observatoire de la presse du Burundi

Institut de Développement Economique du Burundi

(IDEC)

Observatoire de l'Action Gouvernementale (Burundi)

Platforme de la Societé civile du Burundi

Voix des sans voix

RDC Humanitaire

Pole Institute

B'Tselem

Palestinian Centre for Human Rights

The Geneva Initiative

al-Haq

Breaking the Silence

The Peres Center for Peace

MA'AN Development Center

I'Lam Arab Center for Media Freedom Development and

Research

Addameer Prisoner Support and Human Rights

Association

Palestinian Center for Development \& Media Freedoms

The Palestinian grassroots Anti-Apartheid Wall Campaign

Plateforme des ONG françaises pour la Palestine

The Syrian Observatory for Human Rights

Syrian Network for Human Rights

Violations Documentation Centre

Damascus Center for Human Rights Studies

Kosovo Foundation for Open Society

Kosovo Civil Society's Consortium for Sustainable

Development

Balkan Investigative Reporting Network (BIRN)

Macedonian Helsinki Committee

Women's initiative ANTIKO

Foundation Open Society - Macedonia

Association for Emancipation, Solidarity and Equality of

Women

Transparency Macedonia

Human Rights Watch

L'ONG Chrétienne contre la Torture et la Peine de

Mort (ACAT)

Action contre la Faim
Transnational and local NGO

Local (Burundi)

Local (Burundi)

Local (Burundi)

Local (Burundi)

Local (Burundi)

Local (DRC)

Local (DRC)

Local (DRC)

Local (Israel/Palestine)

Local (Israel/Palestine)

Local (Israel/Palestine)

Local (Israel/Palestine)

Local (Israel/Palestine)

Local (Israel/Palestine)

Local (Israel/Palestine)

Local (Israel/Palestine)

Local (Israel/Palestine)

Local (Israel/Palestine)

Local (Israel/Palestine)

Local (Israel/Palestine)

Local (Syria)

Local (Syria)

Local (Syria)

Local (Syria)

Local (Kosovo)

Local (Kosovo)

Local (Kosovo)

Local (Macedonia)

Local (Macedonia)

Local (Macedonia)

Local (Macedonia)

Local (Macedonia)

Transnational

Transnational

Transnational 
Appendix I. (Continued)

NGO

Transnational and local NGO

Doctors without Borders

Transnational

American Jewish Council

Transnational

Amnesty International

Transnational

Care International

Transnational

Conciliation Resources

Transnational

Coordination Sud

Transnational

European Academy (EURAC)

Transnational

Frères des Hommes

Transnational

Deutsche Friedensgesellschaft

Transnational

Gesellschaft für bedrohte Völker

Transnational

Group for Research and Information on Peace and

Transnational

Security (GRIP)

International Committee of the Red Cross

Transnational

International Alert

Transnational

International Federation for Human Rights

Transnational

Ligue des droits de l'homme

Mouvement contre le racisme et pour l'amitié entre les

Transnational

peoples (MRAP)

OXFAM

Transnational

Pax Christi

Transnational

Physicians for Human Rights

Transnational

Transnational

Reporters sans Frontièrs

Transnational

Save the Children

Transnational

Search for common ground

Transnational

Caritas

Transnational

Secours Islamique

Transnational

Stop the War

Transnational

War on Want

Transnational

Transnational

Zentralrat der Juden in Deutschland

Transnational

\section{Appendix 2a: Examples of the automated coding (epistemology)}

\section{Excerpt from a Human Rights Watch Report on the DRC from 2012:}

The worst attacks were against the Mbororo nomadic cattle herders who frequently traverse the border between Congo and the Central African Republic (CAR). At least 35 Mbororo women and girls were raped. Some women were taken to army camps where they were held and repeatedly raped. Soldiers also beat and arbitrarily detained Mbororo men and pillaged their cattle. The army claimed the Mbororo were aligned with the LRA, but provided no evidence to support the claim. 
Armed groups also attacked civilians. In the east, the FDLR and Congolese armed groups occupied areas vacated by government soldiers when they were temporarily recalled for training, attacking civilians who resided there. For example, in May FDLR combatants attacked numerous villages in Masisi territory, killing six civilians, raping two women, and abducting at least 48 people whose whereabouts remain unknown.

In this case, the dictionary identified two concepts from the list of epistemological statuses:

1. The concept 'no evidence' that is part of 'uncertainty' markers was identified because of the combination of 'evidence' with 'no'. One of the search terms that describe 'no evidence' is 'evidenc*_y(no|not|cannot|lack*|insuff*|need* 5)' meaning that the concept will be coded if the search term evidenc* ${ }^{*}$ means that any number of additional letters can follow) can be identified together with one the search terms in the brackets in a word distance of 5 words.

2. The concepts 'Unknown/Not Know' that is part of 'uncertainty' markers were identified because of the word 'unknown'.

\section{Appendix 2b: Examples of the automated coding (sources of evidence)}

\section{Excerpt from a Human Rights Watch article on the DRC from 5 February 2013:}

The M23 has received significant support from the Rwandan military since the group's inception. Rwandan military officials have planned and commanded M23 military operations; supplied weapons, ammunition, uniforms, and other equipment; and recruited hundreds of young men and boys in Rwanda to join the rebellion, according to Human Rights Watch research.

The occurrence of sources of evidence was measured based on a list of expressions. Here, the usage of 'according to' indicates that this text contains references to sources of evidence. Each sentence that was identified with this method was extracted hereafter (in this case starting with 'Rwandan military officials ...'). Finally, the origin of evidence ('research') and the author of evidence ('Human Rights Watch') were identified with the help of a list of potential authors and origins based on the dictionary. 